\title{
ORIGIN STORIES:
}

THE PROVENANCE OF FOUR ARCHIVAL PRINTS OF DEATH WEEKEND (1976)

\author{
By
}

Aisling Yeoman

BA Cinema Studies and English, University of Toronto, 2001

\author{
A thesis \\ presented to Ryerson University \\ in partial fulfillment of the \\ requirements for the degree of \\ Master of Arts \\ in the program of \\ Film and Photography Preservation and Collections Management
}

Toronto, Ontario, Canada, 2018

(C) Aisling Yeoman, 2018 


\section{AUTHOR'S DECLARATION FOR ELECTRONIC SUBMISSION OF A THESIS}

I hereby declare that I am the sole author of this thesis. This is a true copy of the thesis, including any required final revisions, as accepted by my examiners.

I authorize Ryerson University to lend this thesis to other institutions or individuals for the purpose of scholarly research.

I further authorize Ryerson University to reproduce this thesis by photocopying or by other means, in total or in part, at the request of other institutions or individuals for the purpose of scholarly research.

I understand that my thesis may be made electronically available to the public. 
Origin Stories: The Provenance of Four Archival Prints of Death Weekend (1976)

Master of Arts, 2018

Aisling Yeoman

Film and Photography Preservation and Collections Management

Ryerson University

\begin{abstract}
Even as contemporary film studies programs incorporate archival studies into courses, conventional film history, criticism, curatorial writing, and scholarly discourse rarely consider the physical characteristics and technical information intrinsic to the print itself or, indeed the negative elements from which prints are generated. Through an examination of four archival prints of Death Weekend (1976) - a film co-produced by Cinépix and Quadrant Films with funding from the Canadian Film Development Corporation - the thesis proposes a condensed timeline of key events in the life cycle of the prints starting with creation at a film processing lab and ending with acquisition by an archive. The thesis demonstrates that each print is physically unique and has unique provenance. It shows the importance of these factors, seeking to correct the rampant marginalization of the work of the lab and archive by privileging their contributions and foregrounding the preserved prints as rare objects.
\end{abstract}




\section{Acknowledgements}

I would like to express my gratitude to my first and second readers, Alicia Fletcher and Marta Braun, both faculty of Film and Photography Preservation and Collections Management at Ryerson University. Alicia, thank you for your continuous guidance and for encouraging me to write about the preservation of "the B.” Marta, thank you for challenging me and aiding in the distillation of my writing.

I am indebted also to Thierry Gervais and Don Snyder at Ryerson for their constructive comments while I pursued topics related to Cinépix and Lionsgate in their courses.

My heartfelt thanks to everyone at Library and Archives Canada in Gatineau, Québec for a wonderful learning experience while I researched my thesis and completed a work placement there. Special thanks to my supervisor, Steve Moore, as well as Caroline Forcier-Holloway, Nicolas Granger-Gothscheck, and Pascal LeBlond. J'aimerais remercier tout le monde á Bibliothèque et archives Canada pour une merveilleuse expérience d'apprentissage.

Many thanks to Paul Gordon and Christina Stewart for sharing their knowledge and expertise with me. It was a dream come true to be able to inspect the prints in this thesis and I learned much from the experience.

I am indebted to Rachel Beattie and Rachel E. Beattie for assisting my research over the past two years.

Thank you to Malini Guha and André Loiselle for discussing ideas with me.

Many thanks to my family and friends for their support. 


\section{Table of Contents}

Author's Declaration for Electronic Submission of a Thesis.........................ii

Abstract........................................................................

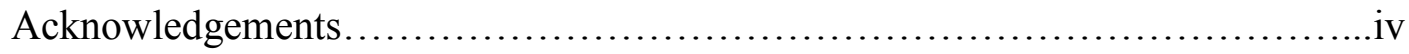

Introduction: Absences and Indifferences...................................

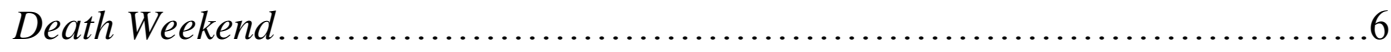

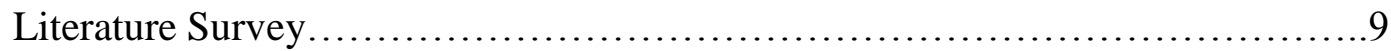

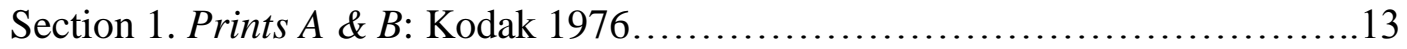

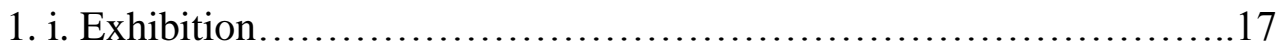

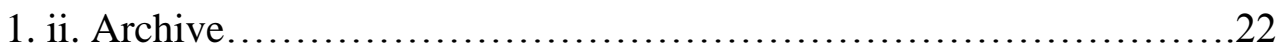

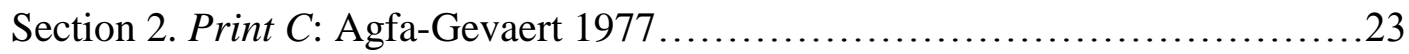

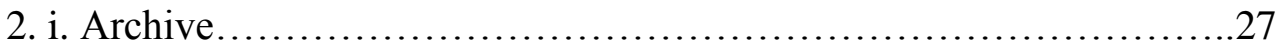

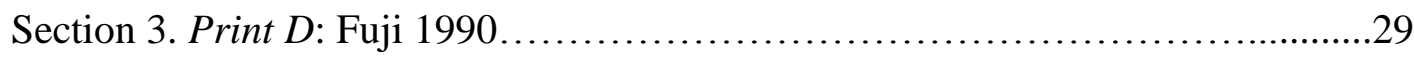

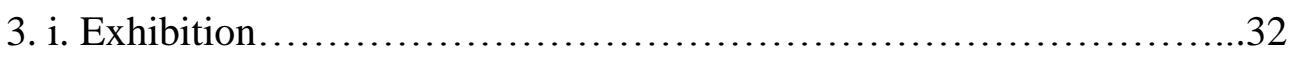

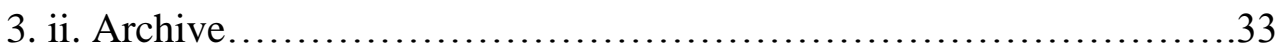

Section 4. Outside the Archive: Contemporary Exhibition........................35

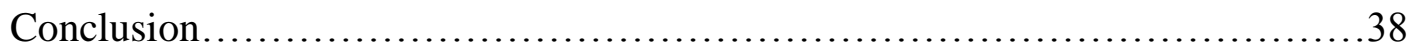

Appendix: List of 35mm Death Weekend Prints and Elements....................41

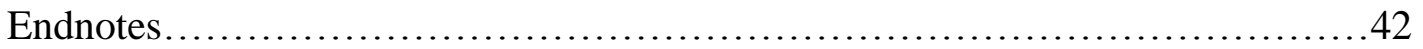

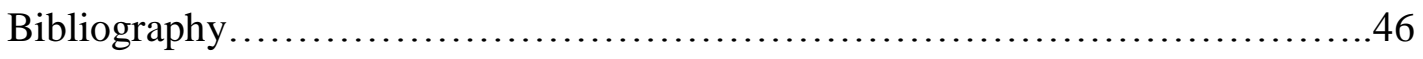




\section{Introduction: Absences and Indifferences}

Discussion of individual film prints and their preservation is a subject largely absent from or confined to the margins of many types of film writing. Even after the so-called "archival turn" in the 80s and 90s in which theory-centred and text-based film studies were displaced by primary source research and historiographical rigour, and as contemporary film studies programs incorporate archival studies into courses, most conventional film history, film criticism, curatorial writing, and scholarly discourse rarely considers the physical characteristics and technical information intrinsic to the print itself. Exceptions include case studies of a silent film restored from multiple, partial prints; comparisons of different versions of a film cut by the censors at the time of release; or a brief line in curatorial notes about the condition or type of print (e.g., archival, newly struck). However, what format(s) a film exists in, where it is preserved, what lab processed it, or its current condition are more often than not omitted so that the content of the film or perhaps its historical context can take centre stage. Although not without its critics and not confined to a single methodology, the analysis of form and content or theory is still the traditional basis of cinema studies. It is possible to generalize, indeed, that most writers, whether they are reviewers, academics, curators, or historians, usually focus more on what is visible when a film is screened, streamed, or played than anything else. What risks being lost and rendered invisible by this tendency towards content is the material object itself, the film print and its history.

Generally programmers, academics, and critics do not consult prints first-hand in an archive, nor do they request access to their elements. This is often for practical reasons such as the inability to travel to inspect prints or an archival policy that denies access to them. Scholars and critics often do not have film handling training and many archives don't allow researchers to touch prints so there is certainly a good reason for such omissions. Yet, the crucial practices that ensure the long-term sustainability of and future access to films are minimized in scholarly discourse. The cumulative effect of downplaying the prints themselves and their preservation is that valuable avenues of research are ignored. ${ }^{1}$ 
If the track record for attention to individual prints is pretty bad, it is even worse for the production elements from which they are generated. The internegatives, the duplicate negatives, the colour reversal intermediates, or the optical and magnetic soundtracks are buried even further in the footnotes if they aren't ignored altogether. The nuances and differences between various image and sound elements rarely find their way into film writing. One result is that the important role of the processing lab in the chain of film production is effectively erased.

The dearth of information pertaining to the material object, its elements, and their origins in the lab is matched by a lack of attention to the print in the archive and its manner of preservation. Such omissions appear to be based on assumptions that there are numerous copies of films in archives (as well as available in other formats such as online streaming and DVD) and that the prints of a given film are all the same. In reality, prints are unique artifacts with different physical characteristics. They can be different versions or types of prints (e.g., an answer or a release print), diverse gauges (e.g., 16mm or $35 \mathrm{~mm})$, or be in better or worse condition.

The provenance of a print or prints is another factor commonly ignored in film writing. In her chapter "Provenance Research in Museum Collections" in the fifth edition of MRM5: Museum Registration Methods Karen D. Daly defines provenance. She writes, “[t]he word 'provenance' literally means 'origin;' yet it also refers to the history of ownership, particularly of an artwork or artifact."2 She continues, "[t]he objective of provenance research is to trace the ownership history and location of an object, ideally from its creation to the present." 3 The twenty categories of object and provenance information in the template in MRM5: Museum Registration Methods include the following: artist/maker, date of work, date of acquisition, signatures and marks, description, provenance, and exhibition history. ${ }^{4}$ Under the section for "provenance" the template stipulates the inclusion of "at the minimum, known owners, dates of ownership, places of ownership, method of transfer..."

Provenance research in a museum setting is traditionally undertaken to authenticate art objects, that is, to confirm that they are by whom they are purported to be and that they are lawfully owned by the donor or seller currently offering them to the museum. Research prior to acquisition is often pursued by a 
curator and is designed to ensure against any future liability of the museum or other purchaser in the event that an artifact is later discovered to be stolen or looted.

Provenance has different meanings and implications in the context of a film archive. Film archives may not have the staff or funds to do extensive provenance research nor is it necessarily of utmost significance for them to describe where a print was every day of its existence. Since many of the items are donated, and donors often gift more than one object over their lifetime, there is mutual trust between the archival professionals accepting a print and the donor which negates the need for lengthy and time-consuming investigation into provenance. Additionally, making provenance information public - in metadata as an example - is not desirable when the archive wants to protect the identity of the donor. ${ }^{6}$

There are other problems when provenance models are borrowed from art history and applied to film. The objects are inherently different. The director is often considered the intellectual and artistic "creator" of a work, especially given the continued perseverance of the auteur theory in many academic circles. But if one is talking about the physical object, i.e. the film print in its plastic or metal containers, and not about its narrative content, the print was most likely never owned by the director nor did she or he actually create it. It was usually owned by the distributor and created by lab technicians. Therefore, its provenance wouldn't include the director. One goal of this thesis is to expand the definition of provenance to include the lab where the prints were struck in order to tell a more accurate origin story of the prints. What may seem like a technicality - that the prints are owned by the lab until they are paid for - is actually very important in the study of the provenance of film prints as I hope to demonstrate.

Writing with respect to the digital restoration of early films for release in DVD versions, curator Paolo Cherchi Usai bemoans "the absence of any indication of the archival provenance of individual titles" in "Early Films in the Age of Content; or 'Cinema of Attractions' Pursued by Digital Means."7 He notes that along with absenting the name of the archive which preserved the film and makes it available for current view from the credits on the DVD box, packaging or streaming site - thereby erasing its work - this tendency to downplay the role of the archive is tied to a general devaluation of the physical object being preserved: the film print itself. Its origin and its history are not made visible and the film is treated 
as "content" only. He writes: "The film print, with all its specificities and characteristics, has become 'a film;' that is, the actual print source and the name of the collecting institution responsible for its preservation appear to be irrelevant. Apart from its ethical considerations, this practice highlights a chronic indifference toward the 'internal history' of the print: where it was found, how it had been used and by whom, which collection policy prompted its acquisition, and how it was preserved."8

Although Cherchi Usai is writing specifically about the implications of digital technology on the preservation of early cinema and the absence of archives or processing labs in the credits on restorations, his ideas are applicable beyond their original context to any cinematic genre or time period. This thesis seeks to address this “chronic indifference” by taking Cherchi Usai's concept of an “'internal history' of the print" as its focus in order to explore the origins and history of four prints of the 1976 Canadian film, Death Weekend. The thesis illustrates how each print is physically unique and has unique provenance, and shows the importance of these factors. In doing so it seeks to correct the rampant marginalization of the work of the lab and archive by privileging their contributions and foregrounding the preserved prints as unique objects.

The thesis combines primary source archival research with secondary sources and hands-on physical inspection of four prints. The latter produces valuable information about the print's history and can reveal vital information and evidence of its singularity not visible when the film is projected. My focus is especially on the edges and the leader, and therefore, spaces not visible in projection.

The thesis is not an exhaustive history of the four prints, an impossibility given the time frame and word count of the project. Instead of a detailed history, it proposes a condensed timeline of key events in the life cycle of four archival prints of Death Weekend. This life cycle includes creation at a film processing lab, circulation in theatres in original release, storage between original release and entrance into the archive, and acquisition by the archive. Public exhibition in repertory screenings is also considered as part of the print's life cycle and its circulation.

In the absence of any models of a print history in the same vein or detailed study of provenance with respect to multiple prints of the same film, as well as the difficult nature of this type of research, this 
thesis can only be a beginning or partial history based on a combination of primary source textual research, print inspection, personal interviews, and educated guesses. Nevertheless it suggests how each print has unique physical characteristics and has a unique provenance, as well as how the knowledge of their uniqueness adds value to the prints. 


\section{Death Weekend}

Alternatively labeled as a drama, thriller, or horror film, and within the horror genre, as an example of the subgenre of rape-revenge, Death Weekend (1976) was the only co-production between two of the most influential film companies devoted to genre filmmaking in 1970s Canada: Cinépix Inc. and Quadrant Films Ltd. ${ }^{9}$ Cinépix was founded in Montreal in 1962 by John Dunning and Wilfred Dodd as a distribution company. ${ }^{10}$ André Link joined the company after a few months and he and Dunning became life-long business partners. In 1968 Cinépix entered production with Valerie (Valérie), which was released in 1969 and became the first film to make \$1 million at the box office in Québec. Cinépix was known for producing low-budget genre fare, including horror, comedy, and sexploitation, although it also released European arthouse pictures and early works by Québec auteurs Denys Arcand, Francis Mankiewicz, and Claude Jutra. Besides Death Weekend, Cinépix produced or co-produced Shivers (a.ka. The Parasite Murders) (1975), Meatballs (1978), Happy Birthday to Me (1981), Making It...Safe (1987), Princes in Exile (1990), and Ski School 2 (1995), among others. Cinépix briefly merged with exhibitor Famous Players in 1989 as Cinépix Famous Players and then reorganized on its own as Cinépix Film Properties in 1994. In 1997 the company was purchased for \$36 million in cash and shares by Frank Giustra of Lions Gate Entertainment and renamed Lions Gate Films. ${ }^{11}$

Quadrant Films Ltd (also known as Quadrant Releasing) was a production and distribution company founded in Toronto. British ex-patriot Peter James and David Perlmutter produced or coproduced nine films, predominantly horror flicks, between 1972 and $1979 .{ }^{12}$ Initially Quadrant funded horror films made in the US by American directors Ted V. Mikels (The Corpse Grinders, 1972, and Blood Orgy of the She-Devils, 1973) and Bob Clark (The Night Walk a.k.a Deathdream, 1972, and Children Shouldn't Play With Dead Things, 1972). Other treasures from Quadrant's catalogue include Deranged (1974) and Prom Night (1980). After Quadrant dissolved, James wrote a series of popular police procedurals while Perlmutter headed up First Choice pay TV network, among other projects. ${ }^{13}$

Death Weekend was written and directed by William Fruet. It was produced by Ivan Reitman with Dunning and Link as executive producers. Don Carmody was associate producer. It starred 
American actors Brenda Vaccaro (as Diane) and Don Stroud (as Lep). Canadians in the cast included Chuck Shamata (as Harry), Richard Ayres (as Runt), Kyle Edwards (as Frankie), and Ed McNamara (as Spragg).

Death Weekend was shot between 27 October and 1 December, 1975 in studio and on location in Kleinberg and Toronto, Ontario. It was filmed in Eastmancolor with Panavision cameras and has an aspect ratio of 1.85:1. The film was made with assistance from the Canadian Film Development Corporation (CFDC) and Famous Players Film Company. The budget was $\$ 500,000$ with an additional $\$ 250,000$ as a loan from the CFDC. ${ }^{14}$

Both Cinépix and Quadrant's entries into production coincide with the creation of the CFDC and both companies took advantage of available government funding. ${ }^{15}$ The CDFC was created by Parliament in 1968 (after it was first tabled in 1967) to promote Canadian feature film production with an initial budget of $\$ 10$ million dollars. It was set up to " foster and promote a feature film industry in Canada" 16 and "to help fund low-budget productions." ${ }^{17}$ It functioned as a bank to loan funds with the idea that profitable films would return money to the CFDC. Up until this point, Canadian feature film production was mainly confined to the National Film Board of Canada (NFB) and the Canadian Broadcasting Corporation (CBC).

In 1974, the government instituted a $100 \%$ Capital Cost Allowance as an incentive to producers. Based on a point system that rewarded the number of Canadians involved as cast and crew in any film, it was designed so that a producer could write off up to $100 \%$ of their investment. Although the federal government had previously tried tax incentives to spur production in Canada, including a $60 \%$ Capital Cost Allowance Program (CCAP) in 1954, the $100 \%$ Capital Cost Allowance resulted in a boom in production. It gave rise to the tax shelter film, which refers to films produced between 1975 and 1982 under this scheme. Such films are usually associated with the horror genre, but there were comedies and dramas made as well. Outside of Quadrant or Cinépix titles, such films included Rituals (1977), The Silent Partner (1978), Murder by Decree (1979), Les bons débarras (1980), Porky's (1981), and Who Has Seen the Wind (1977). The $100 \%$ Capital Cost Allowance had the desired effect at least on one level: 
foilm production in Canada increased rapidly. Nevertheless it was largely considered a failure. By 1984 the government had reverted back to the $60 \%$ scheme and later it was completely abolished. Also in 1984, the CFDC was reorganized as Telefilm Canada, the name by which it is still known today.

Although most tax shelter films did not make money, and some were not even released, Death Weekend was profitable both at home and abroad. Prior to its Canadian theatrical release in September of 1976, it screened as part of at least two major European festivals. First, it unfurled on the morning of 20 May, 1976 at the Cannes Film Festival. During the prestigious French festival, and in the months immediately following its premiere, Death Weekend was pre-sold to "all available markets" to the tune of $\$ 800,000 .^{18}$ (This was a repeat of Cinépix’s stellar previous year when David Cronenberg's Shivers played at Cannes and made back its government loan through advance international sales well before it even opened in Canada.) Death Weekend also won awards. In 1976, Fruet was given the grand prize at the Sitges Film Festival. He also won Best Screenplay there while Brenda Vaccaro was honoured with Best Actress for her performance.

Starting in September 1976, Death Weekend was released in Canadian cinemas in both $16 \mathrm{~mm}$ and $35 \mathrm{~mm}$ formats ${ }^{19}$ as well as in both official languages. The Canadian French-language release title was Fin de semaine inférnale; however neither French prints, nor $16 \mathrm{~mm}$ are considered in this thesis. 


\section{Literature Survey}

While the literature pertaining to the materiality of Canadian low-budget film prints and their preservation is almost non-existent, there are American studies on the preservation of exploitation genres, the films that influenced our own cinematic visions in the 1970s. Two factors, for example, that have a direct effect on the preservation of a film are its original distribution context and print count. Although I have yet been unable to locate Canadian writers who tackle these issues, there are at least two American authors who delve into the topic of print counts and how they relate to preservation of genre cinema. In a Film Comment article titled "Tales from the Crypt," critic Maitland McDonagh transfers the nostalgic ideal of a "lost film" from its usual frame of reference, the silent era, to horror and sexploitation films from the 1950s, 1960s, and 1970s. She notes how outright carelessness by producers and distributors coupled with low print counts have contributed to a contemporary preservation worst-case-scenario she calls "dire." "Low print runs, slapdash record keeping, and a generally pragmatic attitude towards the merchandise imperil movies," writes McDonagh,"but the real killer was the fact that before home video and its successors, laserdisc and DVD, the value of exploitation pictures ended when the theatrical market for their of-a-time brand of shocks and yocks dried up." ${ }^{21}$ Although she paints a grim picture of film companies dropping the ball, McDonagh singles out the valiant preservation efforts of DVD and video distributors William Lustig of Blue Underground and the late Mike Vraney of Something Weird Video for keeping 1970s genre pictures alive, well, and in circulation in home entertainment formats.

Since there are few academic sources which address the preservation of B-films, horror, and exploitation film, McDonagh's contribution as a journalist is a useful resource and point of departure for a study of the preservation of a film which falls into some of these categories. Issues of genre and labelling are frequently thorny and problematic since most films are not "one" thing. Building on some of the same ideas as McDonagh is Casey Scott's 2011 Final Essay for New York University's Master of Arts in Film Preservation program, "Issues in Preservation of Exploitation Cinema." While McDonagh transposes the idea of rarity normally associated with nitrate prints of silent films onto horror films from the 1960s and 1970s in the earlier piece, Scott throws down the gauntlet when he estimates the number of prints for the 
average exploitation film's theatrical release to be in line with that of some avant-garde films.

"Exploitation films," he argues, "share several characteristics with more often championed genres such as experimental and avant-garde works, but the most obvious is a low print count." ${ }^{22}$ Scott claims the number could be as low as 6 prints from a negative. He also cites Joseph Rubin who collected sexploitation and adult films from 1969 to 1986 and who thinks $75 \%$ of the negatives and camera positives of such films from that period are lost, and the positive print situation is equally bad as there were never many prints to begin with. "With so few prints available of many titles, each one becomes more valuable and important to preserve, ${ }^{, 23}$ Scott writes. With a nod to the work of his thesis advisor Dan Streible, Scott suggests that the designation of "orphan film" be extended to exploitation as it already has been to pornography. For Scott, a huge part of the reason why academia shuns these types of films and why the literature on them is sorely lacking is directly related to their print counts. The lack of their preservation is attributed to the fact that archives and their policies are biased against exploitation and genre film. Many archives prefer to preserve and promote art cinema or films seen as having more cultural or historical value. ${ }^{24}$ For these films to be studied with the seriousness worthy of their merit, they need to be preserved and accessible to scholars. For Scott, it is independent collectors and distributors who are carrying the burden of preserving these essential works instead of traditional archives.

Two recent appraisals of Death Weekend, both multi-page discussions, are found in larger books about Canadian horror cinema, which analyse the film in those regards. In The Canadian Horror Film: Terror of the Soul, published in 2015, edited by Gina Freitag and André Loiselle, author Paul Corupe unpacks Robert Forthergill's tropes of masculinity focusing on the impotent male character as a specifically Canadian type while delving extensively into the negative reviews of the film in his chapter, "(Who's in the) Driver's Seat: The Canadian Brute Unleashed in Death Weekend." ${ }^{25}$ His argument then shifts to an extended comparison between Death Weekend and a later, more notorious, American example of the rape-revenge film, Meir Zarchi's I Spit on Your Grave (1978), considered by some to have been influenced by the earlier, Canadian film. 
Another contemporary take on Death Weekend is found in Caelum Vatnsdal's 2004 book-length study of Canadian horror, They Came From Within: A History of Canadian Horror Cinema, ${ }^{26}$ which was updated in 2014. Vatnsdal's tome is vital as the only book-length history of Canadian horror to date. He gives pride of place to Link and Dunning as progenitors of the genre in Canada, notably for igniting a wave of horror pics that started in the 1970 s and endured into the 80 s. The author reserves a special place for Death Weekend in the chapter, "You should know how bad this movie is; after all, you paid for it," which covers the seminal years 1975-1977 when David Cronenberg first knocked on Cinépix's door and Canadian horror emerged from the shadows. Vatnsdal's treatment of the film is far less involved, encompassing approximately three pages as opposed to Corupe's seventeen, although it is no less incisive.

The literature on the CFDC is more copious. In his chapter titled "Film History/Film Policy: From the Canadian Film Development Corporation to Telefilm Canada" in Self Portraits: the Cinemas of Canada after Telefilm, edited by Tom McSorley and André Loiselle, the author Peter Urquart's aim is to chart "the narrative of feature film policy in Canada." ${ }^{27}$ In so doing he launches a critique of the prevailing perception of the tax shelter era as a "national sell-out to Hollywood" 28 as argued in an essay on the subject in a previous iteration of the same book by Pierre Pageau. At the same time as Urquart departs from his predecessor's assertion, he argues for a "significant reconsideration" of the period. ${ }^{29}$ What Urquart finds particularly problematic is the assumed dichotomy between art and commerce eternally at the heart of discussions of our national cinema. Notably he discusses the committee meeting in 1964 in which two options for Canadian cinema were identified: art cinema and low-budget "second features," ${ }^{30}$ that is, a double bill with the "B" or a low budget genre film projected second. While emphasizing that the market for the latter had run its course by this time, he affirms that, the audience for that type of film and content was still there. Death Weekend decidedly falls into this second category, as do a number of films from the early years of the CFDC. Urquart makes the point that the government policy had a "flawed starting point" 31 since it didn't really consider the distribution of the films, only their 
production. The result was that although the government was technically loaning the money, it was more accurately giving grants to the tax shelter films since most failed to make any money back. 


\section{Section 1. Prints $A$ \& B: Kodak 1976}

This thesis explores the materiality and provenance of four $35 \mathrm{~mm}$, English-language prints of Death Weekend in two Canadian archives that I inspected (see Appendix I for more details). ${ }^{32}$ The first two I address are Canadian, English-language release prints made in 1976. One each is housed in Library and Archives Canada (LAC) in Gatineau, Québec and the Media Commons at the University of Toronto (UofT). The LAC print is designated as a "projection" print and the UofT print is designated as a "circulation" print. ${ }^{33}$ Effectively they mean the same thing: that the prints may be projected on screen or can be loaned out for public exhibition, as opposed to preservation or master prints which cannot be loaned or exhibited and must remain inside the archive. Of the prints investigated in the thesis, the two Canadian release prints have the longest and most complicated history.

Both prints share a base of cellulose acetate and are printed on the same Kodak film stock. The edge codes indicate that the stock was manufactured in 1976, the same year Death Weekend was released. It is impossible to narrow the timeframe of when the prints were struck any further than the year, at least based on print inspection alone. This is because Kodak edge symbols correspond only to the year of manufacture and do not include the lettering characteristic of some film manufacturers that manufactured stock on a quarterly basis and included the initials of months in edge codes. Examples of such edge codes on print stock produced by Agfa-Gevaert and Fuji will be discussed later.

Any composite, positive print is by definition the offspring of multiple negative elements. What is now a single unified object with sound synchronized to picture was preceded by negative material in which image and soundtrack were made and stored separately. A print's forbearers may run the gamut of an interpositive (IP), an internegative (IN), a Colour Reversal Intermediate (CRI), an optical or magnetic soundtrack or other types of elements.

There is no indication on these Canadian release prints of Death Weekend of the name of the lab where they were struck. No lab name is found on the film cans in either archive. These two prints, as well as the other prints of Death Weekend, list the names of three laboratories in their end credits: Quinn Laboratories, Bellevue Pathé Ltd, and Film Opticals Ltd. Yet the metadata in LAC's database, MISACs, 
does not include any of the labs responsible for its 1976 print. Neither does the metadata at UofT. Published in 1987, The Canadian Film Index created by John Turner - LAC's first archivist dedicated to acquiring feature films - mentions only Quinn in his entry on Death Weekend. ${ }^{34}$ Turner had published the same production information about Death Weekend a decade earlier in Cinema Canada. He was a regular contributor to the magazine where he reported on Canadian films in production. His column from the December-January 1975 issue cites Quinn as the only lab associated with Death Weekend. However, he also gives the film's production dates as October 27-December 1 and indicates the status of the production at "picture editing." 35 This means his data on Death Weekend was compiled and printed before or just after the film stopped shooting late in 1975 and approximately ten months before release prints were made for Canadian distribution. The entry for Death Weekend in The Canadian Film Index is, for the most part, taken verbatim from the 1975 column, and as a result, records the name of the only lab associated with the film in 1975. It follows, then, that the entry did not include the names of the labs that struck the Canadian release prints. They were not yet in existence when it was compiled. They were more than likely created the following year, closer to the Canadian release date of 17 September, 1976. It is certainly possible that Quinn did in fact strike the release prints, but since there are two other labs credited directly on the release prints there are at least two other possibilities.

My best guess is that Quinn, based in Toronto, probably processed the dailies and possibly the camera negatives as well as performing technical work such as colour correction. It would make sense to rely on a lab close to the shooting locations, which were Toronto and Kleinberg, Ontario, to process the rushes overnight so that the producers and director could review them the next day. Based on the credits, it seems Film Opticals was responsible for creating the opening and end credits, as well as perhaps special effects through optical printing.

It would make sense if the intermediate negatives were made at Bellevue Pathé which was near Cinépix headquarters in Montreal for convenience rather than being shipped back to Toronto. I am relatively certain that both the LAC and UofT prints were struck at Bellevue Pathé in Montreal from sound and image negative elements also created there. 
On reel one of the LAC print there is information identifying the production and distribution companies in white capitals on black leader: "PICTURE: DEATH WEEKEND, COMPANY: DAL PRODUCTIONS, SERIES: CINEPIX, REEL NO.: 1A (sic).” DAL Productions - an acronym for "Dunning and Link" - was a subsidiary of Cinépix Inc. set up for the express purpose of tracking government funding, in this case likely to follow the expenditures of a loan from the CFDC. Series, in this case, refers to the distributor, Cinépix, which was the lab's client or customer. This identifying information is handwritten, rather than typed. The same writing is found on the UofT print, linking the two prints.

What does the print preserve that cannot be found elsewhere? In addition to the printed words discussed above that appear in white capital letters at the head of the LAC and UofT prints, there is another set of matching handwriting on the edge of the leader. The most prominent handwriting - the capital letters on the centre of the leader - is likely that of the technician who struck the prints. The other set of writing is much smaller and appears only on the right side of the leader further along than the title and client information. The smaller handwriting is also in capitals, but distinctive for the manner in which the film's title is broken up into three words: "Death" "Week" "End"). These markings on both prints make reference to a track, reel, and foot. The fact that both sets of handwriting are the same on both prints links them together and back to a shared negative source. It also supports the case that these prints were created at the same time, by the same technicians, in the same batch, at the same place.

But what can be said about the negatives used to make these two prints? The positive prints are not in their original cans, but luckily at least some negative elements in the UofT collection are. They include one Kodak internegative (IN) discussed below and one Agfa Colour Reversal Intermediate (CRI) soundtrack. They reside in Bellevue Pathé metal cans labelled "Internegative" and "CRI", respectively. In some cases the reels are also inside clear plastic bags branded with the lab's name, address, and phone number inside the container. Thus there is no mistaking where the negatives were struck. Given the replication of the smaller handwriting I am convinced that both UofT and LAC's 1976 Kodak 35mm prints were generated from the CRI. As with all photographic materials, what appears as white writing on 
the positive print is black on one of its negative ancestors, the CRI. Similarly, the optical soundtrack's black undulations register as white on the positive print. On the CRI, the waves appear at the edge of the translucent, lavender Agfa negative stock. The huge empty space on the negative element is blank so that when the image and sound elements are brought together the larger area will be taken up by the frames of images on the positive prints with the optical track beside them. The two 1976 prints at LAC and UofT share traces of their negative ancestors, at least one of which was Kodak and another which was Agfa. Besides the edge codes, the words "Kodak" "Eastman" and "Safety Film" repeats along the edges of both, which could be from the IN.

Since the history of Canadian film processing labs is not well-documented and distribution company paperwork pertaining to prints and labs from the 1970s would in most cases be long lost or shredded by now, being able to link the prints to one and possibly two negative elements is significant. Knowing where the negatives were created can aid in the identification of a print's lab of origin because it may have been struck at the same lab as the negatives.

The head of each of the reels of the LAC print feature censor stamps from Ontario and British Columbia embossed over a few frames. They appear over the credits on the first reel for example, indicating that the film was approved for release in both provinces. The stamps are a visible record etched into the surface of the prints of where, precisely, the particular print circulated. Such physical evidence of where the print was used can only be seen during print inspection on a bench since the translucency of the stamps ensures they remain invisible during projection. While the LAC print's two seals show it circulated theatrically in two provinces, the UofT print in contrast has only the Ontario stamp.

There is another 35mm English-language print which I located, but did not see, in the collection of the Cinémathéque Québècoise (CQ). Yet I am confident that it is also on Kodak stock and dates to 1976. This is because it was donated the same year, 1987, and by the same donor, Cinépix, as the LAC print. ${ }^{36}$ Both prints were in storage at Victoria Shipping in Montreal just prior to donation. The print is currently housed in the CQ's vaults in Boucherville, Québec, the facility where the archive's prints have been stored since the early 1970 s. ${ }^{37}$ 
I would also postulate that the CQ print bears the identical handwriting on its leader to that on the LAC and UofT prints, both the small and large capitals. The CQ print should also demonstrate evidence of projection and use like the other two prints, including splices, dirt, and broken perforations since it was an original release print like they were. It will have faded, but my best guess is that it will be less pink than the UofT print and possibly in better condition because it has been stored longer inside an archive and circulated less. Like LAC's print, the CQ print has been archived since the late 80s, while the UofT print may have been used more and circulated, remaining out of the archive longer and accessioned more recently in 2008. The CQ print may have a different combination of censor stamps than those described above, including the possibility of a Québec stamp because the film was also released in that province. Further research could include inspection of the CQ print.

\section{1.i Exhibition}

While impossible to prove, it is probable that after the LAC or UofT prints were struck from negatives at Bellevue Pathé, one of them was sent to the Imperial Theatre in Toronto where Death Weekend opened on the cinema's fifth screen on 17 September, 1976 where it played for five weeks. ${ }^{38}$ Like the legendary Uptown theatre, the Imperial at Yonge and Dundas was part of the Famous Players theatre chain. During the 1970s, the distribution system in Canada was much different than it is today. Films did not open simultaneously on the same weekend at multiple cinemas. There was no such thing as a wide release. Instead, a small number of prints were struck and they would travel from one city and theatre to another. ${ }^{39}$

The Imperial had been converted from a live theatre venue into a multi-screen cinema a few years previously in 1973. Gerry Flahive reminisces about this landmark theatre known for its B-film offerings and as a "precursor to the multiplex," 40 in the 2003 article "Palace of Guilty Pleasures" in The Toronto Star. The films, he recalls, were "a diet of sugar-highs, heavy on fat, with an occasional side dish of substance." 41 
It was customary for films produced by Cinépix to play at the Imperial. For example, Ilsa the Tigress of Siberia, aka. The Tigress opened on 5 November, 1977, also in cinema five, and lasted two weeks. Other classic Cinépix tax shelter films, My Bloody Valentine and Happy Birthday to Me, both 1981, screened at the Imperial in their first runs. ${ }^{42}$

The LAC print bears a British Columbia censor stamp, so although I was unable to access listings or records that captured the details, we know that in addition to its release in Ontario, Death Weekend was also released there. As for Québec, according to a Cinépix press release from 30 September, 1976, the film was released that day at Le Parisien and Dorval cinemas in Montreal. ${ }^{43}$ Like Toronto's Imperial, the two Montreal theatres were affiliated with Famous Players. Because Death Weekend was partially funded by Famous Players, a theatrical release at the chain's cinemas was probably part of the original financing deal. But neither the UofT nor LAC print bears a Québec censor stamp and so neither archive’s prints played in the province. Available data, however, shows that the film had circulation in at least three markets - Ontario, B.C. and Québec - and that within each it played only in one or two theatres in a major city and a few smaller places. The point is, this film didn't have a huge circulation. ${ }^{44}$

During a Cinépix film's theatrical release such as that at the Imperial, prints were briefly taken out of circulation and then put back into circulation again. When its run at a particular theatre came to an end it would be sent to Victoria Shipping a.k.a. Victoria Film Services, a depot at 237 Le Bourget Street in Montreal, also referred to simply as "the shipping." ${ }^{45}$ The UofT and LAC release prints are no exception. Victoria Shipping ads in the Canadian Film Digest during the 1970s describe their services as: “DEDICATED TO SOLVING ALL FILM-HANDLING PROBLEMS COMPREHENSIVE, UNIFIED, DEPENDABLE SHIPPING, REVISING STORING FOR 35MM AND 16MM FILMS.” (sic). After arriving at the depot, the film would be "revised," which included the cleaning of the film and the mending of broken sprockets, before being sent out to a new theatre. Victoria Shipping was also a place where films were stored after a film's theatrical release, so it is likely that intermittently throughout its year of release, 1976, our two prints were still circulating regularly in and out of the depot before becoming more permanent residents there as the years passed by. 
Besides its theatrical release and travels to and from the Victoria Shipping warehouse, a print of Death Weekend played in at least one curated film series in Toronto between its initial release in 1976 and when the two prints were accessioned in 1989 and 2008 respectively. It is possible indeed that one of the two prints currently archived at LAC and UofT was the one that screened on Thursday, 10 July, 1978 at 7:30pm in the Lecture Hall at the Art Gallery of Ontario (AGO) at 317 Dundas Street in Toronto.

Repertory screenings, series and retrospectives are programmed for a niche audience of film buffs at venues that include arthouse cinemas, independent theatres, museums, and art galleries. Repertory screenings represent a different kind of exhibition context and circulation outside of the original release context of the film and generally occur some years after the film retired from theatres. Ways in which repertory screenings of a film are different than a current release include economic and logistical factors. Unlike an initial release in which a spectator can choose from multiple showings per day, when a film is borrowed from an archive or loaned by a distributor or other rights holder, it is usually for a flat fee or a percentage and the film is screened for one night only (with exceptions obviously such as when a new print is struck of a title). This single showing is designed to maximize the potential box office profit by ensuring that as many interested spectators show up at the same screening instead of multiple screenings, while minimizing wear to the print. It is part of the loan policy of many film archives that an archival print only be screened once for an audience per loan period so as to minimize wear and the possibility of damage to the print. Other archives permit multiple screenings.

Curatorial framing through repertory programming can often reclaim films that were ignored or slammed by critics at the time they were released. In the case of Death Weekend, which was uniformly dismissed as trash, each repertory screening is a case for reevaluation and an opportunity to create a new context for the film. One of the ways in which programmers or curators at repertory cinemas create new contexts in which the modern spectator can appreciate a film from a past era is through juxtaposition with other films as part of a series. Films are often grouped by genre, director, actor, theme, or country of origin, but there are many more inventive ways programmers combine films. Screening related films together can highlight shared stylistic elements and themes or draw out points of contrast between films. 
In addition curators often provide written program notes which act as arguments for what is important or interesting about a film, as well as to contextualize it.

The AGO screening of Death Weekend was part of a series called "Hollywood North" which included three other films: Between Friends (1973), Partners (1976), and Shivers. Admission was free to all screenings. Death Weekend and Shivers were restricted to persons 18 and older. All four films were introduced by director, producer, and screenwriter Don Owen and the series was presented in conjunction with the National Film Board of Canada. The AGO screening may have been the first public screening of this film outside of its original release in theatres (at least for an English-language print) although it is hard to say for sure since repertory exhibition of films from this period is not well documented. ${ }^{46}$

The curatorial notes for "Hollywood North" framed the selected films in relation to the country's burgeoning commercial film industry, their status as entertainment, and goal to connect with a wide international audience. This series, therefore, effectively contextualized for a public audience the ongoing debate that had been raging in the media ever since the CFDC was created in 1968, a controversy that reached a crescendo when journalists lambasted the government and Cinépix over the funding of David Cronenberg's Shivers. This 1978 repertory series removed the discussion of whether genre cinema had a place in our nation's film industry from the floor of the House of Commons and brought it into a venue where the tax shelter taxpayer could judge the films for him or herself. The program notes for the series, printed on a promotional leaflet at the time and currently archived at the AGO, highlight the ever-present difficulties attending Canadian films in a marketplace dominated by Hollywood films, challenges which continue in our day. The notes read: "[b]y removing four of the industry's more intriguing products from their original commercial context - where they usually compete with American films - one can perhaps identify what is (or is not) distinctive about the Canadian approach to contemporary genre material."${ }^{, 47}$ Was the print loaned by Cinépix for "Hollywood North" one of the two original release prints currently at UofT or LAC? Possibly. Because, I believe, only two prints circulated in Ontario and the number of prints struck overall was small. 
Although I was unable to determine the exact number of $35 \mathrm{~mm}$ Canadian release prints struck in 1976, based on my research and taking into consideration such factors as number of theatres, print data for other Cinépix films, and number of preserved prints in archival hands, I estimate that there could never have been more than six English-language release prints and the number could be as low as three.

Three would mean $100 \%$ of the prints are presently preserved in three archives (LAC, UofT, $\mathrm{CQ}$ ), and it would mean that no prints were destroyed in projection, lost in the depot, or taken home by a Cinépix staffer or someone who worked on the film. It would assume no backups were made or no copies bought by a collector. Three is perhaps less plausible than a higher number, but it is theoretically possible. The original print count can't be less than three because the film played in a minimum of three theatres in English simultaneously when it opened: the Imperial in Toronto where it opened first, and La Parisien and the Dorval in Montreal where it opened a week or two later. Since both have Ontario censor stamps it is possible that the prints at LAC and UofT, were the only prints which circulated in Ontario. There would likely not have been more than one print released in British Columbia - the LAC print. Producer Don Carmody, credited as associate producer on Death Weekend, recalled in an email how only a few prints of films were struck at this time because there was no such thing as a wide release. Prints would be recycled and moved around between venues and there is evidence the prints were re-used between different releases. There are signs of modern projection on both the LAC and UofT prints in the form of accordion splices. $^{48}$

By 1987 there were two prints in the depot, according to donor correspondence, with one each snapped up by LAC and CQ. If the original print count was three, then this would mean Cinépix held onto the third and it ended up in the possession of Lionsgate and ultimately was donated to UofT. If the print count was six, then half of the prints are presently preserved in Canadian archives, which is an excellent rate of preservation.

This is all to say that the original print was low and counters the idea that there are multiple copies of this film or of other films from this time period "just lying around." If there were only a 
maximum of six 35mm English-language release prints in Canada, it becomes statistically more likely that one of these archived prints was shown in the venues outlined in this thesis.

\section{1. ii. Archive}

It is typical that an object's entrance into the archive and absorption into a collection can take place over several years or more. Decisions have to be made in keeping with an archive's policy and there are multiple steps and people involved which may include the shipment and receipt of the artifact, its accession, and processing. The process of LAC ushering its original $35 \mathrm{~mm}$ release print into the collection took place over a period of three years from the initial offering of the gift from a donor in 1987 to its accession in 1989. In December 1987, a list of Cinépix-produced films held at the "depot," i.e. Victoria Shipping in Montreal, was sent to LAC. A note from Rita Ebe-Leone of Cinépix addressed to archivist John Turner invited him to peruse the list of films it didn't have use for anymore and to respond to her letter noting any prints it might want to add to the collection. ${ }^{49}$ There were at least two prints because Cinépix made a similar offer to the Cinémathèque Québécoise, which is why the Montreal institution also has an English-language release print of Death Weekend. As to why the prints were donated at this particular time, I assume that the prints had run their economic course for Cinépix and were no longer of use a little over a decade since the film was released. In any case, the prints donated by Cinépix to LAC (and CQ) in 1988 were shipped directly to the archives from Victoria Shipping. ${ }^{50}$ It's impossible to know how long they were held there before they became a part of their respective archives; it could have been for as much as a decade before they found their way there. 


\section{Section 2. Print C: Agfa-Gevaert 1977}

The third print this thesis considers is an American release print made in 1977. It is also in LAC's collection and was acquired in 1978. Thus, this was the first print of Death Weekend in the national archives until the 1976 Kodak Canadian release print described in the section above was acquired in the late 80 s. In contrast with that print which screened theatrically and on additional occasions outside of its original release context, LAC's American release print of Death Weekend has a clearer and much less complicated history. It is easier to account for where it was created, its movements, its moments of stasis, and its changes in custody. This is because it was a release print that was never actually in release.

Described by the archivist as a new waxed print in excellent condition when it arrived at LAC, ${ }^{51}$ this US release print was sired from a CRI in Hell's Kitchen, Manhattan sometime between April and June of 1977. Or at least the two capital letters and four numbers burnished on its lilac-tinged, Agfa stock suggest a spring or summer birthday. (The edge codes read "AJ 1977”).

This is the only print discussed here in which the name of the processing lab is truly "internal" to the print, that is, is written on the print itself. ${ }^{52}$ White letters on top of black leader spell out "Movielab Part 1," repeated over multiple frames of reel one. Presumably each subsequent reel is labeled Part 2, Part 3, and so on. Thus Movielab, the name of a once-bustling lab located at 619 West $54^{\text {th }}$ St. in New York City which no longer exists, is preserved in black and white on this print of Death Weekend. This physical evidence in the form of the lab's signature on the print validates information about the originating lab recorded in LAC metadata and documents.

In addition to carrying the laboratory's name, the head leader is stamped "Customer: AIP," a reference to Death Weekend's US distributor, American International Pictures (AIP). In the context of the lab and the creation of prints as an economic transaction, the "customer" is usually the distributor. It is generally their responsibility to strike a certain number of prints depending on a film's schedule of theatrical engagements. It is also the distributor's job to pay the lab for the prints. In addition to its name appearing on the leader in several places, the AIP logo appears after the concluding frame of the leader, that is, just before the commencement of the title sequence of the film itself. This is one small way in 
which this print differs from the Canadian release prints i.e., there is no optical of a distributor logo on either Canadian version.

AIP is perhaps the most well-known American production and distribution company devoted to B-fare from the 1950s through the 1970s. AIP released Death Weekend on 4 March, 1977 under the title The House by the Lake. It was packaged as a double feature with a re-release of Wes Craven's The Last House on the Left (1972), a key work in the rape-revenge canon although it is unclear whether the double feature was in all markets and in the first year of release. I have only found an AIP advertisement which touts three similarly-titled films - The House by the Lake, The Last House on the Left, and The House That Dripped Blood (1971) - as playing simultaneously, although it is unclear if this means they are a triple feature or just playing at the same time. ${ }^{53}$ The copyright notice on the ad reading "Copyright 1980 American International Pictures" indicates the film was still circulating at least three years after it debuted in the US. There is deliberate symmetry between the two titles - The House by the Lake and The Last House on the Left - both of which seem innocuous in comparison to their subjects, countering AIP's standard titling practices, but certainly AIP wanted to connect the pair of films in the minds of fans of Craven's first feature. AIP had previously released Cinépix's Shivers in the US under the title, They Came From Within. Like Death Weekend it was part of a double bill, playing next to the original snuff movie, Snuff (1975).

AIP had a relationship with Movielab and relied on the skills of its technicians on a regular basis. The lab's name is enshrined on the US poster for The House by the Lake near the bottom of the list of credits. It reads "Color prints by Movielab." Other AIP posters from this period credit Movielab. For example, Movielab is credited in the same manner on the iconic US promotional posters for They Came From Within and Deranged, among others. Additionally, Movielab is frequently credited for "Color" (not “color prints") on posters and ads - including on the original 1972 poster for Last House on the Left indicating that the lab was known for colour correction and other post-production work, in addition to creating prints. 
In addition to AIP's name, the American title, "SUBJECT: THE HOUSE BY THE LAKE” (sic) is written in black letters on the clear leader. After the leader and the AIP logo the credits start and the title simply reads "House by the Lake" in red letters even though the film was frequently advertised as "The House by the Lake."

Like the two Canadian release prints above that originated from a combination of both Kodak and Agfa negative materials, the US release version is printed on Agfa stock, but was generated from a Kodak negative. The blonde leader lady or "China Girl" (a woman or mannequin with a gray scale below or beside her - a feature that aided film labs in controlling colour timing or black and white density) who appears across multiple frames at the head of the print captures and conveys this ancestry vividly. The leader ladies on this print of Death Weekend represent examples of those mass-produced by Kodak, a practice the company started at this time. Prior to the mid-1970s, it was customary for labs to create their own ladies, something that would endow uniqueness to prints. It is possible that this print captures this cross-over period, but further research would need to be done into the intricacies of Kodak leader ladies and their usage by labs in Canada and the United States.

The presence of the leader lady on a print is physical evidence of the lab and processing. It is always a reminder and a trace of an unknown technician and his or her work. Several duplicate frames of this same image would be affixed by the technician to each reel of a negative for the purpose of checking colour on prints produced from it. Dressed in brightly-patterned clothing, the leader lady on the American print appears next to a large number "77" in white numerals, a smaller Kodak insignia, and "76 ECN II." The appearance of the lady with the numbers " 77 " would seem to confirm that the print was struck in 1977 from a Kodak negative. The letters "ECN" stand for "Eastman Color Negative." The number II refers to the chemical process which created the precursor negatives to this print and the number 76 designates the year associated with the chemical process. ${ }^{54}$

The American print now housed at LAC reminds us that rarely is there one original for a film; there are only multiple originals and overlapping stories between the negatives and prints. While LAC metadata indicates the American print on Agfa was struck from a 35mm CRI, it is impossible to know 
exactly from how many negatives it was actually made. Certainly one was Kodak because the Kodak name is right there on the print, Kodak's leader ladies are on the leader and the chemical process was proprietary to Kodak. This American print illustrates Cherchi Usai's ideas particularly well. The lab's name is etched on the print, as is as other information about how and where it was created, by whom, and how it was used.

On each reel of this American print there is information handwritten in white script on the edges of the head leader repeating the title and customer name, as well as the track and reel numbers. On its tail leader the title is repeated as are the reel number and the customer. The Canadian title Death Weekend is also visible, scratched out right before the words "End" and "Picture." A cross follows, filling a single frame. The writing on the sides of the head leader differs from that at the tail and reflect the contributions of at least two technicians in the creation of this print and its negatives. The writing along the sides of the head of the print appears to be from the soundtrack negative since the word 'track' is inscribed in a manner similar to the small handwriting on the two 1976 prints. All in all, there is less handwriting on the US than on the Canadian prints because its title and customer name are typed on the leader and not transcribed by hand by a Movielab employee.

While I have not located any other 35mm American prints, the edge codes indicate that LAC's American print could not have been struck at the same time as any made for the opening weekend of 4 March, 1977 in the US. Its edge codes date the stock to between April and June, 1977. It could perhaps have been part of a second print run after the film had played in theatres for a couple of weeks and they struck more prints than were needed.

Further to the edge codes, which document the print's belated creation at least a month after the film's US opening, there is written evidence that the print was struck by mistake. A 20 February, 1978 transcribed phone message left by André Link for archivist John Turner alerted him that there was a "mint print of Death Weekend in N.Y. struck by mistake." ${ }^{55}$ Since this print was never supposed to exist its existence is all the more special and its preservation all the more miraculous. In keeping with the likelihood that this print was struck by mistake and never circulated in theatres, I also believe this print 
has never seen the light of a projector or flown through its gate. In other words, it has never been projected. According to LAC Senior Film Conservator Paul Gordon, also an experienced projectionist, my 'never-projected' theory is hard to prove, yet he concedes that the only blemishes on the print are mild scuffing along the edges; and they could have come from the processing of the print at the lab, from using power rewinds or putting the film on a Steenbeck.

Even if it has been projected before, the fact that this is an immaculate AIP print, on Agfa, with the company's name in multiple places on the leader and with the China Girl intact, ${ }^{56}$ makes it an incredibly valuable artifact. If there are any other superfluous $35 \mathrm{~mm}$ US prints created by mistake on the same day when Movielab created the LAC print, and if they remain in mint condition because, like this print, they were archived practically on creation and never were in release, my best guess is that such a print would be somewhere in the vaults of MGM, the ultimate owner of AIP's catalogue. However, prints and elements of films produced by AIP - as opposed to films produced by other companies that were distributed under its name - would most likely have been the company's priority for preservation. Further work on this subject would include more investigation into American prints of this film.

\section{2. i. Archive}

In contrast with the two Canadian prints above, the US release print never circulated in theatres. It went straight from the lab that created it to the archive that adopted it in 1978. It has spent most of its life in preservation and was designated as a preservation or master print when it entered the archive. But even as its designation limited its circulation both inside and outside the archive, my hypothesis that it has never been projected does not mean that it has never been used or accessed prior to my own research. LAC records indicate that the print was inspected soon after it arrived so it was accessed by LAC staff to create the accession record and note the metadata now found in the print's MISACs entry.

Another way in which LAC's U.S preservation print has been put to use was to create a VHS copy for public access, a copy which I viewed on a television prior to inspecting the four prints. The VHS has the AIP logo, and therefore is the American release version of Death Weekend. According to its 
database, LAC also possesses a second VHS version. This tape, however, was not made by LAC. Instead it seems to be a branded video dating to the film's VHS distribution by Astral Bellevue Pathé, the same company that struck the negatives and probably struck the prints, in the early 80s. It was donated in 1984 as part of the Astral Bellevue Pathé fonds which features video copies of other films they distributed in Canada. This second video has been misplaced, however, so I was unable to compare the tapes. To my knowledge there are no access copies made from UofT prints or elements. Although it was released on VHS more than once, Death Weekend has still never been released on DVD in North America.

As a master print destined to remain in the archive and not to be lent out for public screenings, is it possible that the American print has ever left LAC's premises, even once? It was most definitely moved from its initial resting place in Ottawa along with the rest of the national archive's film collection to LAC's Preservation Centre in Gatineau, Québec, a state-of-the-art facility which opened in June $1997 .{ }^{57}$ The print is preserved there currently in the colour vaults. Likely LAC's Canadian original release print was transferred at the same time.

The provenance of the US print is unique for a number of reasons. First, it is the only print discussed here that was not acquired through a donation by either Cinépix or Lionsgate. It is also unique because it was never owned by its distributor, AIP. Its chain of ownership consists only of lab and archive since the print was bought in a simple purchase and sale agreement between Movielab and LAC in 1978. 


\section{Section 3. Print D: Fuji 1990}

The only print of Death Weekend struck later than 1976 or 1977, the Canadian and U.S. release years, is in the Lionsgate Collection at UofT's Media Commons. It is longer than the other prints described here: the LAC Kodak print is 7954 feet, the UofT Kodak version is 7925 feet, and the LAC Agfa print is 7955 while the Fuji print is 7450 feet. When asked about whether the difference in length might be significant, whether the Fuji print might even be another version, Media Commons Assistant Media Archivist, Christina Stewart, suggested that the thinner stock could account for the disparity. Of all the prints discussed the Fuji print is also the one for which there is the least data available as to when and where it was struck or why. Unlike my hypotheses about the other prints, and the particular economic and cultural context for each, I can only guess at the Fuji's origin story and why it was created fifteen years after Death Weekend's initial release. However, this print's aura of mystery is precisely what makes it an excellent case study with which to apply Cherchi Usai's idea of an internal history of the print. It still contains clues to its own identity and to that of its negative forbearers which are visible on the physical object.

The mystery print is on Fujicolor stock and has a triacetate base. It is in excellent condition with a vibrant, bright colour. Stewart recorded the shrinkage rate in her Motion Picture Film Condition Report of all five reels dated April 2, 2017 as between .4 .5 - .5 percent for each reel, with the exception of the second reel, which is less shrunken and registers at $.3-.4$ percent on the shrinkage gauge. Stewart places its decomposition rate as "Good" or "O" and its overall condition as "Very Good" or "1.5," i.e. the print is cut with few or no signs of wear." This is because the print is not dusty, dirty, faded, brittle, or moldy. However, Stewart noted scratches on all five reels and damage to reels 3 and 4 in her condition report.

The cue marks at the end of the reel I inspected were hastily-drawn diagonal lines with grease pencil. They are clear evidence that this print has been projected and that it has circulated. There is a small amount of white dust on the plain black, tail leader, but there is no evidence of any decay on the rest of the reel. Indeed, of the three circulation or projection prints I was able to inspect closely at LAC and UofT's preservation facilities, the Fuji print is in the best condition with the least amount of damage, dirt, 
and splices. This makes sense as it is the youngest print and Fujicolor is a relatively low-fade stock. Kodak started selling Eastmancolor stocks that were more resistant to dye fading in 1979, but LAC and UofT's prints both demonstrate the fading associated with the earlier versions. Of the two original release prints from 1976, the LAC print is in better condition in terms of colour fading, although I only inspected it on the bench and never saw how any of the films looked projected on the screen. The UofT copy is definitely pinker when shown next to LAC's. Gordon explained that the colour of LAC's print would not look as bad in projection as it did on the bench. Viewing the print up close with the loupe it was easier to see the gradations in colour, confirming Gordon's comment. According to both Stewart and Gordon, the archival professionals I consulted, all four prints are projectable. None of their shrinkage rates extends beyond .5 percent, and therefore all are in the acceptable range for projection.

As for LAC's US, struck-by-mistake print, the stock is light purple with a dark purple soundtrack. Built up into the full reel on the rewinds the print looks eggplant. The colour in the image is vibrant with no fading as Agfa is a relatively low-fade stock and the print looks pristine when run on an interciné in LAC's Preservation Centre. The difference in colour between the Canadian prints and the US version is particularly evident in the opening sequence in which Diane and Lep race their cars. The red of the villain's car is brilliant in comparison with the faded Kodak prints.

But to return to the Fuji print: the Fuji stock's edge codes are "90 JS," dating it to sometime between July and September of 1990. But we do not know where it was struck. Most likely the print was created in either Toronto or Montreal because Cinépix (called Cinépix Film Properties or Cinépix Famous Players at the time) had headquarters in both places and its labs were based primarily in these two filmcentric urban areas.

There are a few curious features on this print which bear traces of its negative ancestors and history. First, the tail leader on reel one has a piece of masking tape which says "Bellevue Pathé" "Roll 1 (No. du Rouleau)," and “Customer 1 (No. du Client)" on it.

However, the leader could not have been produced in 1990 because Bellevue Pathé had either closed by then or been renamed. ${ }^{58}$ So the head leader on the 1990 print was probably recycled from 
another print or element. The fact that Bellevue Pathé - the same lab which created the original negatives and most likely the prints - has it name on the leader suggests that an old leader may have been attached when the new 1990 print was struck from an old Bellevue Pathé element, the result of technicians handling multiple elements and their cans.

The second curious feature on this print concerns the leader lady and is an example of how checking the negatives can aid detective work on prints. The leader lady on the 1990 print is identical to her sister on the Kodak internegative also preserved at UofT, except, of course, the negative image is reversed as a positive on the print. The fourth and final image of the lady on the IN is spliced in the middle of the frame, something that is duplicated on the print (again, in positive) and which further confirms their relationship to each other. Yet unlike on the US print, there are no proprietary Kodak branding or dates. ${ }^{59}$ Looking closely at the first frame of the leader lady on the Fuji print, one can see traces of sheer blue marker which spell out part of a Spanish title, Fin de semana sangriento or "Bloody Weekend" although it is very hard to read. Why are there Spanish words on an English-language print?

The Kodak IN's original container helps to explain the presence of Spanish words on this print. The container's label has black type featuring Bellevue Pathé's name, its address “2000 Ave Northcliffe Ave.," and the blue rooster logo. There are printed letters in blue pen describing the contents inside which read, “Cinepix, Death Weekend, 1/35 Interneg, Bob $4=7 \& 8$ 1378'." There is also a green shipping label below. This paper label includes the following information "Cinecolor S.A," "Buenos Aires - Argentina," "Negativo Color," "Tragico fin de semana," "Dia: 26, Mes: 5, Ano: 82," and "in 5 rolls." In other words, the IN was shipped back to Canada on May 26, 1982 from Cinecolor S.A., the lab in Buenos Aires that struck the prints for the 1982 Argentinian release of the film.

While creating prints for Death Weekend's Argentinian release, a lab technician in Buenos Aires apparently wrote the film's Spanish title on an IN loaned from Cinépix. The words "Fin de semana sangriento" are scrawled in marker across the first frame of the leader lady. They are difficult to read, but are still visible. In addition to the title scribbled atop the leader lady, Spanish words appear in several other places on the IN. Although the twinning leader ladies and repeated splice make eloquent cases for a 
relationship between internegative and print, it is the tell-tale handwriting in Spanish, passed down from element to print, that affirms their relationship. The lab technician's subtle alteration of the IN years ago gave the element a distinguishing characteristic reproduced on this Fuji print seemingly struck several years later from the same IN used to produce prints in South America. In this way, the print itself documents part of the film's circulation history and where it was released outside of North America. It also shows how the original elements were used as Cinépix continued to make distribution deals and exploit potential markets for the film, continuing the circulation of prints several years after the initial Canadian release.

\section{3. i. Exhibition}

The fact that the 1990 print bears the traces of the film's 1982 release in Argentina doesn't explain why a new print was struck in 1990, however. One possible answer is that this is a Swedish release print struck in Canada and sent to Scandinavia. According to the Internet Movie Database, as well as the Swedish Film Institute's database, Death Weekend was released theatrically in Stockholm on 17

August, 1990 by the distribution company GeBe Film AB ${ }^{60}$ It was released in Sweden with no translation or change of title, suggesting that the film was released in English rather than dubbed or subtitled into Swedish. A number of other Canadian films of this period were released in Sweden also with their Canadian release titles, including Rip-Off (1971) and Spasms (1982), pointing to the possible practice of distributing Canadian films in English there. It is entirely conceivable, therefore, that the Fuji print archived at UofT is the same print that played at the Biografen Rigoletto theatre in the Stockholm. The best evidence on the print which supports its possible use in the Swedish theatrical engagement are the edge codes. As noted above, they read " 90 JS", which means that the stock was manufactured between July and September of 1990. If it was indeed made for this exhibition context and released on 17 August in Sweden, one can narrow the creation date of the print to either July or early August of 1990. It is also possible that this print did not circulate in Sweden, but was created at the same time for a screening 
somewhere else or for the purposes of preservation. But further research will be needed to substantiate any claims about this mystery print.

\section{3. ii. Archive}

Like the UofT 1976 release print (B), this Fujicolor print (D) came to UofT's Media Commons as part of the vast contents of the Lionsgate Entertainment fonds, which was gifted as a single donation. The accession number for the entire Lionsgate fonds is 2008.003 and the dates of creation are 1968 to $2007 .^{61}$ In contrast, the content of LAC's Cinépix fonds, which includes the 1976 Canadian release print (B) and 1977 US print (C), was built up through multiple donations over many years. And while the LAC Cinépix fonds contains only moving image material (albeit in a range of formats), the Lionsgate Collection comprises 163.65 metres of textual records, 46,864 photographs, 1,680 graphic material, 5,567 audio recordings, 19,008 video recordings, 6,010 cinefilms, and 1,613 electronic records. ${ }^{62}$

A production and distribution company, Lionsgate was created in Vancouver in 1997 partly through a reverse takeover of Beringer Gold Corporation by Lions Gate Studios. As announced in a press release in January 1998, Cinépix was purchased by Lionsgate founder Frank Giustra in 1997 and renamed "Lions Gate Films." ${ }^{93}$ Cinépix Film Properties had been trying to become a publicly traded company for the previous decade when the offer came in. Dunning, Link, Michael Paseornek, and Jeff Sackman transitioned to executive roles within Lionsgate when Cinépix was absorbed by the larger company.

The UofT Lionsgate fonds contains material pertaining to films both produced and distributed by Lionsgate, as well as the output of purchased companies, including Cinépix. The archival arrangement of the massive Lionsgate fonds is in the form of ten series with various subseries nested within it. Two prints of Death Weekend (the 1976 Kodak and 1990 Fuji prints) are part of the fourth series, "Cinépix (Audio Visual Files)." Within this series, these prints (and their negatives) are part of the subseries "Audio Visual Film Based Elements." In turn, there are sub-series for this and twenty-one other Cinépix productions christened according to film title. In addition to Death Weekend, there are prints and/or elements for Le 
diable est parmi nous (Satan's Sabbath) (1972), Across This Land with Stompin' Tom Connors (1973), Vibrations (1996), Whispers (1990), and more.

The bequest that included the two Death Weekend prints and was accessioned in 2008 may have in some way been linked to the company's tenth anniversary. A donation of this size would result in a very large tax credit for the donor, along with the potential freeing up of office and storage space, of particular benefit to an independent company. Part of the incentive for the preservation of prints is the economic facts that they cost money to create and cinema is a product that does not go home with the consumer, unlike many other goods. With the material housed at UofT, Cinepix and Lionsgate could continue to access the films for the purposes of distribution in different markets, including the lucrative home entertainment platforms.

The 1976 release print at UofT started out as property of Cinépix and entered the archive as an asset of Lionsgate. It remained in the hands of Cinépix for much longer than its siblings donated to LAC and CQ in the late 1980s. It has therefore probably circulated more than the other two prints, which explains why it may be in worse condition. Its unique provenance encapsulates a number of corporate name changes of the same company, iterations which include Cinépix, Cinépix Film Properties, and Cinépix Famous Players. Thus more than the other prints do, its chain of ownership reflects a deeper history of Cinépix and its evolution over the years, as well as its relationship to Lionsgate. 


\section{Section 4. Outside the Archive: Contemporary Exhibition}

The films produced by Cinépix are fairly well-preserved in Canadian archives. It is impossible to speak to the condition of each film print or the completeness of each negative deep in the vaults, but it is fair to say that the company's output will be protected for posterity since it made sure to deposit more than one copy of their films in multiple locations - at LAC and CQ during the heyday of Cinépix, and later, with UofT. Each of these archives has done its job. They've preserved this film and the other contributions of a company that has shaped our nation's cinema even if most people have never heard of it. But the Canadian archival prints of Death Weekend don't circulate as much as, perhaps, they should.

Tax shelter films have enjoyed renewed interest lately and Death Weekend is no exception. LAC's projection print was loaned to the Mayfair theatre in Ottawa where it played on 30 June, 2008, as part of a "Canada Day Eve" triple bill with 70s tax shelter classics, Rituals and The Silent Partner. ${ }^{64}$ Tickets were $\$ 10$ and the screening was presented by the Lost Dominion Screening Collective, a group of programmers dedicated to presenting $35 \mathrm{~mm}$ and $70 \mathrm{~mm}$ archival prints. The print was returned to LAC in Gatineau on 2 July in good condition, although a splice had broken on reel two and had to be repaired. ${ }^{65}$

It is possible that the Fuji print of Death Weekend played at UofT's Innis Town Hall on two occasions: Monday, 5 December, 2011 and Friday, 22 February, 2013, both at 7:00pm. ${ }^{66}$ Although it was not recorded in UofT metadata so it impossible to verify that it was definitely this Fuji print that screened. Rachel Beattie, Assistant Media Archivist at Media Commons, confirmed in an email that prior to 2011 information about where and when prints were loaned out was not recorded. Statistics from the time period starting in 2011 indicate that the Fuji print was likely never loaned for public exhibition outside of film classes at UofT and possibly these one-off, un-recorded screenings at Innis. UofT's 1976 release print is labelled with the recommendation not to screen it in the Excel sheet that lists the Lionsgate release prints and it is possible that it has not been projected publicly since its accession in 2008 because the other, 1990 Fuji print is in much better condition.

Death Weekend also played in the CQ's Salle Claude-Jutra at 335 De Maisonneuve Blvd. East in Montreal as part of the Fantasia International Film Festival on 27 July, 2011 at 7:00pm. Kier-La Janisse's 
curatorial note about the film on the Fantasia website stresses the screening as a rare opportunity to view a film which is "[s]till unavailable on DVD." ${ }^{67}$ Death Weekend was part of a six-film tribute to Cinépix called "Maple Syrup Thrills." Dunning and Link were awarded lifetime achievement awards at a celebratory event on 20 July, 2011 at the Hall Theatre before a Shivers screening. To date this has been the only Cinépix retrospective in Canada. The print displayed on this occasion was, however, not one of the Canadian archival prints, but a 35mm UK release print loaned by an American collector, a print which I have not seen in person.

The collector loaned the same print for two further exhibitions of Death Weekend in New York City. First, it played at the seventh edition of the Film Society of Lincoln Center's annual Scary Movies series in $2013^{68}$ as part of a lineup of horror films featuring premieres of new films and repertory screenings of classic films. Death Weekend was programmed alongside two other Canadian horror gems Rituals and Curtains (1983) - creating a mini-retrospective or taste of the tax shelter period for the New York cinephile within a large, multi-film series.

Three years after the Lincoln Center screening, the same collector's print was screened three times, part of the third and final installment of an extensive retrospective devoted to American International Pictures which took place at Anthology Film Archives in New York between 2015 and 2016. The program notes for this final leg of the series highlighted blaxploitation films as well as "a motley selection of one-offs, curiosities, and uncategorizable oddities from AIP's multifarious catalog." ${ }^{69}$ This series is a relatively unique occurrence because distribution and production companies, either contemporary or vintage, are not regularly feted with full scale retrospectives as often as individual directors, actors, or even national cinemas.

While obviously more research would need to be done to trace the source of prints for contemporary screenings of Death Weekend, it seems that the source for prints used at the majority of screenings of this film in North America did not come from Canadian archives. Indeed the archival prints discussed in this thesis have not circulated very much since they were admitted into the archive. 
Why haven't these prints been exhibited more widely since they entered the archives? It is not possible to enumerate all of the possible reasons, but one is that people might not know where the prints are located. In the case of the prints in the Lionsgate Collection, if one doesn't know the connection between the contemporary Lionsgate and the now-defunct Cinépix, they might be hard to find in a fonds that contains multiple series and a vast number of individual items. Another is that for whatever reason, curators may not consider the prints to be in good enough condition, even though all four were pronounced as projectable by the experts I talked to. 


\section{Conclusion}

Although Death Weekend is preserved in multiple archives, many similar low-budget genre films have been thrown out or have disappeared, while those that have survived into the present are worn, faded, and neglected because they were not seen as having any potential long-term value at the time they were made and first circulated. This perception of their worth or lack of it impacts greatly on their preservation in the present. With the high costs of storing and restoring film, the original economic context of a low-budget film can be erroneously equated with its cultural value and significance: if it was made on the cheap and only lasted two weeks in theatres, it isn't worthy of preservation.

Thus, it is very significant that the government of Canada owns a pristine print of a film it supported through a Capital Cost Allowance loan during the first decade in which the CFDC (now Telefilm Canada) was in operation, although the government may still have mixed feelings about its role and not wish to advertise the presence of this print. Nevertheless, the simple fact that it is a US print is evidence that it travelled south of the border. This is a reminder of how Cinépix productions and other tax shelter horror films were some of the first Canadian commercial features to circulate in the US and abroad. These were films which supported CFDC mandates to fund pictures that could compete internationally and turn a profit, with the aim of growing and fostering an industry. Even if, as I suppose, LAC's US print never played or circulated there, others did.

Indeed LAC seized a tremendous opportunity when they purchased the American print directly from the lab approximately forty years ago. It proved to be a very shrewd investment. As an artifact, its value has increased greatly over time and it is a treasure of immense cultural value to Canada and Canadians. Although there are numerous other prints of genre films from the tax shelter period preserved at LAC, this may be one of the archive's only celluloid relics from this crucial era that is in mint condition.

The 1976 release prints are of great cultural value as well. Their blemishes, their broken perforations and scratches, do not decrease their value, but add to it. Their scars tell their history, of their days and nights spent running through the projectors at the Imperial and other theatres long-shuttered. 
Their faded tones transmit the aura of the 1970 s - the drive-ins, the double features - into our multiplex present. The fact that they were used when they entered the archive means they can continue to be used. They are valuable because they can be accessed by scholars and the public or shown to audiences.

The collective value of the prints is augmented by the historical importance of the individual producers, as well as the production and distribution companies involved. It has little to do with the quality of the film, its genre, or its plot. In fact it is its content that keeps Death Weekend off Canadian film top ten lists. A film that has historically been labelled in different places using one or more of the terms exploitation, B-movie, horror, schlock, and rape revenge film is not what we associate with prestige Canadian cinema. Death Weekend is not the kind of film that will ever be found next to Mon Oncle Antoine (1972) on a list of the ten best Canadian films of all time. Nor was it programmed beside an Atom Egoyan film as part of Canada's $150^{\text {th }}$ anniversary celebrations. But maybe it should have been. What it represents is the beginning of the commercial film industry in this country of which it was a part. It is a nexus around which orbit the people and companies who have defined the cinematic landscape of this country from the late 1960 s up to the present.

The importance of Death Weekend - along with other films from the inception of the CDFC in 1968 to the tail end of the tax shelter boom in 1982, including other films from Cinépix's oeuvre - in building this country's nascent industry is an under-represented fact in the accounts of our nation's film history. The Canadian film industry as an industry, as a profitable sector of the economy, was born during the heyday of exploitation. Yet this history has been diminished and erased because the films were lowbudget and they were disreputable. They were made primarily to make money; they were meant to compete with an American product. That was the point - it was part of the CFDC's side of the agreement, the film had to travel and have appeal in other countries, and make a profit. This has made them despised back home.

But you need to do low budget before you do high, Cronenberg had to make Shivers before he could make A History of Violence (2005). It's the same with our industry: the period between 1968 and 1982 - Death Weekend falls in the middle - should be further reappraised as an experimental period in 
Canadian film history. Commercial, genre films funded by the government are not what one normally associates with experimental cinema, which is usually defined as only very, very, low-budget independent cinema. But even the print counts of a film like Death Weekend are closer to those of experimental film than commercial film today. The fact that there were so few prints made testifies to how different the distribution and exhibition systems were in the 1970s. This knowledge of their rarity adds value to the prints described, inspected, and tended to by the archivists and conservators at LAC, UofT, and CQ over the course of the prints' long afterlife in the archive. 


\section{Appendix}

\section{List of 35mm Death Weekend Prints and Elements}

\section{English-language Release Prints}

Archived at Library and Archives Canada (LAC) and University of Toronto (UofT)

Print A: LAC's Canadian Release Print (Kodak 1976) is a projection print* in the Cinépix Inc. fonds. It was donated by Cinépix in 1988 and accessioned in 1989.

Print B: UofT's Canadian Release Print (Kodak 1976) is a circulation print* in the Lionsgate Entertainment fonds. It was donated by Lionsgate and accessioned in 2008.

Print C: LAC's US Release Print (Agfa-Gevaert 1977) is a preservation print** in the Cinepix Inc. fonds. It was purchased from Movielab in New York in 1978 and was accessioned the same year+.

Print D: UofT's Mystery Print (Fuji 1990) is a circulation print* in the Lionsgate Entertainment fonds. It was donated by Lionsgate and was accessioned in 2008.

Additional English-language release prints discussed not at LAC or UofT:

One Canadian Release Print (same as Prints A \& B) in the collection of Cinémathèque Québécoise (CQ) donated by Cinépix in 1988.

One UK Release Print (ca. 1977) in a private collection in the US.

\section{Elements}

Archived at UofT

Element A: UofT's Internegative (Kodak 1976) is in the Lionsgate Entertainment fonds.

Element B: UofT's Colour Reversal Intermediate (CRI) Soundtrack (Agfa-Gevaert 1976) is in the Lionsgate Entertainment fonds.

Legend:

*Projection or circulation prints can be projected and loaned for public screenings

**Preservation or master prints cannot be projected or loaned for public screenings

+ Another accession record was created in 2004 in LAC's MISACs database 


\section{NOTES}

${ }^{1}$ Eric Smoodin, “As the Archive Turned: Writing Film Histories without Films," The Moving Image, 14, 2, (2014): 96-100. Smoodin describes the impact of the archival turn in the 90s and how access to ephemera and textual documents has informed the work of scholars such as Dana Polan, Haidee Wasson, and Lee Grieveson. Yet Smoodin's examples ultimately reveal how access to films in archives is generally still in service to the study of content.

${ }^{2}$ Karen D. Daly, "Provenance Research in Museum Collections: A Collections Management Perspective,"'in MRM5: Museum Registration Methods $5^{\text {th }}$ Edition, ed. Rebecca A. Buck and Jean Allman Gilmore. (Washington: The AAM Press/American Association of Museums, 2010), 62.

${ }^{3}$ Ibid., 62

${ }^{4}$ Ibid., 65.

${ }^{5}$ Ibid., 65.

${ }^{6}$ Ibid., 63.

${ }^{7}$ Paolo Cherchi Usai, "Early Films in the Age of Content; or, 'Cinema of Attractions' Pursued by Digital Means," in The Blackwell Companion to Early Cinema, ed. André Gaudreault, Nicolas Dulac, and Santiago Hidalgo (Hoboken and Oxford: Wiley-Blackwell, 2012), 538.

${ }^{8}$ Ibid., 538.

${ }^{9}$ Cinépix enjoys multiple variations in spelling, both with and without an accent. Company correspondence and documents feature both.

${ }^{10}$ John Dunning with Bill Brownstein, You're Not Dead Until You're Forgotten: A Memoir. (Montreal, Kingston, London, and Ithaca: McGill-Queens University Press, 2014), 47.

${ }^{11}$ Playback Staff, “Andre Link \& John Dunning: filmmaking's 'Odd Couple' celebrates 40," Playback, February 4, 2002, accessed March 29, 2016. http://playbackonline.ca/2002/02/04/tribute-20020204/. There are multiple variations of company name; it is most commonly written as Lions Gate (two words) or Lionsgate (one word). Company correspondence and documents feature both.

${ }^{12}$ Paul Corupe, "From Cinépix to Cineplex: The Studios that Dripped Maple Syrup," Canuxploitation!, accessed December 30, 2017. http://www.canuxploitation.com/article/studio.html.

${ }^{13}$ Ibid.

${ }^{14}$ D.J. Turner, with French text by Micheline Morisset, Canadian Feature Film Index: 1913-1985, (Ottawa: Public Archives Canada/National Film, Television, and Sound Archives/Minister of Supply and Services Canada, 1987), 216.

${ }^{15}$ Corupe, "From Cinépix to Cineplex."

${ }^{16}$ Peter Urquart, "Film HistoryไFilm Policy: From the Canadian Film Development Corporation to Telefilm Canada," in Self Portraits: the Cinemas of Canada after Telefilm, eds. Tom McSorley and André Loiselle. (Ottawa: Canadian Film Institute, 2006), 32.

${ }^{17}$ Mark R. Hasan, "Rituals: Creating the Forest Slasher within the Tax Shelter Era," in The Canadian Horror Film: Terror of the Soul, ed. Gina Freitag and André Loiselle. (Toronto, Buffalo, and London: University of Toronto Press, 2015), 110.

${ }^{18}$ Connie Tadros, "Commercial Results," Cinema Canada, June-July 1976, 22.

19 "Death Weekend One Sheet," Cinépix, accessed December 30, 2017.

http://www.cinepix.ca/downloads/17/Death\%20Weekend\%20\%20Cinema\%20Canada\%20one\%20sheet. pdf.

${ }^{20}$ Maitland McDonagh, "Tales from the Crypt," Film Comment, September-October 2002, 66.

${ }^{21}$ Ibid., 66.

${ }^{22}$ Casey Scott, "Issues in Preservation of Exploitation Cinema," Desperately Seeking MA, October 25, 2011, accessed December 1, 2017. http://nyumawritings.blogspot.ca/2012/10/issues-in-preservation-ofexploitation.html.

${ }^{23}$ Ibid.

${ }^{24}$ Although there are archives with the mandate of preserving genre films and exploitation. One example is the American Genre Film Archive in Austin, Texas: https://www.americangenrefilm.com/. 
${ }^{25}$ Paul Corupe, "(Who's in the) Driver's Seat: The Canadian Brute Unleashed in Death Weekend," in Freitag and Loiselle, The Canadian Horror Film, 91-107.

${ }^{26}$ Caelum Vatnsdal, They Came From Within: A History of Canadian Horror Cinema, (Winnipeg:

Arbeiter Ring Publishing, 2004).

${ }^{27}$ Urquart, "Film HistorylFilm Policy, 32.

${ }^{28}$ Ibid., 30.

${ }^{29}$ Ibid., 31.

${ }^{30}$ Ibid., 31-32.

${ }^{31}$ Ibid., 36.

${ }^{32} \mathrm{I}$ inspected at least one reel of the four prints (A, B, C, D), as well as the elements (A\&B) of Death Weekend considered in this thesis. I was supervised by Senior Film Conservator Paul Gordon at LAC and Assistant Media Archivist Christina Stewart at UofT. My method of inspection for all reels was using rewinds on a bench, with the exception of Print C. Because of its mint condition, I inspected a reel on an interciné and then asked Gordon to handle the film on rewinds so I could take photos and check my hypotheses. Before I inspected prints and negatives at UofT, Stewart completed full condition reports for Prints B and D, as well as compiling an element list which she shared with me. This saved me time and facilitated my access to the negatives. I was then able to use my time in UofT's vaults to compare the UofT prints to those I had seen at LAC, as well as look for possible connections between the prints and negatives. Future work in this area could involve inspection of more negative material at UofT, as well as complete inspection of all reels of each print.

${ }^{33}$ The designation "circulation copy" is attributed to a number of release prints in the Lionsgate fonds listed in an Excel sheet. The 1976 Kodak print of Death Weekend is labelled as "poor condition - do not screen"; however, it is still considered a circulation print (as opposed to a preservation or master print) according to Christina Stewart.

${ }^{34}$ Turner, Canadian Feature Film Index, 216.

${ }^{35}$ D. John Turner, "Feature Film Production Guide," Cinema Canada, December-January 1976, 9.

${ }^{36}$ Jean Gagnon, Director of Preservation and Access to Collections at Cinémathèque Québécoise, personal communication with the author.

${ }^{37}$ Ibid.

${ }^{38}$ Listings for Death Weekend's run at the Imperial can be found starting in the September 1976 section of the Ontario Film Institute's binder for films released in Toronto between 1970 and 1979 at the Toronto International Film Festival Reference Library. The binders, which date back to at least 1950, are an indispensable resource for anyone interested in Toronto film exhibition history.

${ }^{39}$ This researcher checked the Ontario Film Institute Listings binder for a five year period and only found records of the film's run at the Imperial. It most likely played at a few other theatres, in Toronto and elsewhere in the province, but further research would need to be done to reconstruct exactly where and at what theatres from sources such as print advertisements, newspapers listings, and critical reviews.

${ }^{40}$ Gerry Flahive, "Palace of Guilty Pleasures," Toronto Star, July 4, 2003.

${ }^{41}$ Ibid.

${ }^{42}$ All information about Cinépix films playing at the Imperial is taken from the Ontario Film Institute listings binders.

43 “Death Weekend Press Release," Cinepix.ca, September 30, 1976, accessed December 12, 2017. http://www.cinepix.ca/downloads/17/Death\%20Weekend\%20\%20Press\%20Release\%20for\%20opening \%20-\%20Montreal,\%20September\%2030,\%201976.pdf. There is a discrepancy between the Montreal opening date on the release given here, and other sources which list 10 October. For example, D.J. Turner, with French text by Micheline Morisset, Canadian Feature Film Index: 1913-1985, (Ottawa: Public Archives Canada/National Film, Television, and Sound Archives/Minister of Supply and Services Canada, 1987), 216. The release makes it sound like the film was opening the same day it was sent out to the media and there is no mention of a later date of opening.

${ }^{44}$ Contrarily, the entry in The Canadian Film Index says the film was released in five theatres in Montreal and seventeen in Ontario. This seems very high. It means that the film was released in double or triple the 
number of theatres than other films listed in the index from the same period, including Shivers. More research needs to be done to trace exactly where the film played outside of Toronto and Montreal.

${ }^{45}$ Greg Dunning, a producer and John Dunning's son, personal communication with the author.

${ }^{46}$ The history of film exhibitions at the AGO is documented in an Excel sheet in the gallery's archives. See Olivia Babler, “AGO Film - Individual Screenings (1937-1998),” 2016.

47 "Hollywood North [Program Notes]," ca. July 1978, can be found in AGO archives.

${ }^{48}$ Paul Gordon, personal communication with the author. The accordion splices I saw on Print A and B are near the end of the reel. Gordon explained they are evidence of the prints' projection later than the film's original release context of the 1970s; i.e. they must have been exhibited and continued to circulate. These "accordions" are splices made on top of previous splices which overlap each other, and thereby, multiply the area covered by tape. This is associated with modern projection practices in which prints are plattered or multiple reels spliced together onto one large reel so as to minimize the work of reel changes. ${ }^{49}$ The list sent from Cinépix to LAC with the heading "Inventory $35 \mathrm{~mm}$ Prints Canadian Feature Films" from December 1987 can be found in LAC's Cinépix Inc. file.

${ }^{50}$ A receipt from Roger Leger Inc. dated 12 July, 1988 in LAC's Cinépix Inc. file indicates that several boxes containing films were shipped directly from Victoria Shipping in Montreal to Ottawa.

${ }^{51}$ Turner, D.J. "Inspection Remarks" dated 20 March, 1978 in LAC's Cinépix file.

52 There is a possibility that print D, the 1990 Fujicolor mystery print described in Section 3, bears its processing lab's name on its leader, although I think that name instead identifies the lab that struck one of its negative ancestors.

53 "Advertisement for Last House on the Left, The House That Dripped Blood, and The House by the Lake," Real Horrorshow - Poster Gallery, Pinterest, accessed January 5, 2018. https://i.pinimg.com/736x/b2/37/b5/b237b5e0e68b588b874f80efb7355ce6--vintage-horror-vintageads.jpg.

54 “Chronology of Motion Picture Film, 1960-1979,"Kodak, accessed January 3, 2018. https://www.kodak.com/us/en/motion/About/Chronology_Of_Film/1960-1979/default.htm.

${ }_{55}$ Phone message dated 20 February [1978] in LAC's Cinépix Inc file.

${ }^{56}$ It was common practice during the analogue era for projectionists to steal frames of the leader lady/China Girl from prints.

57 "Library and Archives Canada Preservation Centre," Government of Canada, accessed January 6, 2018. http://www.bac-lac.gc.ca/eng/about-us/preservation/Pages/preservation.aspx.

${ }^{58}$ Changes in the names of Canadian film processing laboratories, their dates of operation and of closing, as well as other factual information pertaining to their workings are difficult to trace and often contradictory

${ }^{59}$ There is the possibility that this leader lady is unique to the lab, unlike the version on Print C, the US print, but more research would have to be done to verify this.

60 "Death Weekend (1976)," The Swedish Film Database, accessed December 30, 2017. http://www.svenskfilmdatabas.se/en/item/?type=film\&itemid=20341.

61 "Lionsgate Entertainment Fonds," University of Toronto Media Commons, accessed December 29, 2017. https://mediacommons.library.utoronto.ca/fonds/lionsgate-entertainment. Although the dates of creation for archival material in the Lionsgate Entertainment fonds is given as 1973-2007 online, this is incorrect. There is material in the collection dating back to at least 1968/1969 because there are release prints of Valerie and Le diable est parmi nous.

62 "Lionsgate Fonds."

63“"Independent Film Powerhouse Cinepix Announces Name Change to Lions Gate Films Inc. [Press Release]" January 12, 1998, Lionsgate Corporate/Legal text files, Media Commons, UofT.

64 "The Lost Dominion Screening Collective Screening History," The Lost Dominion Screening Collective, accessed December 29, 2017. http://lostdominion.blogspot.ca/.

${ }^{65}$ Information about the loan and condition of the print are recorded in LAC's MISACs database. ${ }^{66}$ Blake Williams, "This Week in Film: Tower, CINSSU's Cult Night Triple Bill, The Free Screen, Reel Artists film festival,” blogTO, February 21, 2013, accessed January 5, 2018. 
https://www.blogto.com/film/2013/02/this_week_in_film_tower_cinssus_cult_night_triple_bill_the_free_ screen_reel_artists_film_festival/. Williams's article records Death Weekend's 2013 screening at UofT with Rabid and Satan's Cheerleaders, both from 1977. As of 5 January, 2018, information about the 2011 screening, also presented by Innis College's Cinema Studies Student Union (CINSSU), is unavailable online.

${ }^{67}$ Kier-la Janisse, "Death Weekend [program note]," Fantasia International Film Festival, 2011, accessed December 29, 2017. http://fantasiafestival.com/2011/en/films/film_detail.php?id=492.

68 "Scary Movies 7," Film Society of Lincoln Center, accessed December 29, 2017. https://www.filmlinc.org/films/death-weekend/.

69 "American International Pictures, Part 3," Anthology Film Archives, accessed December 29, 2017. http://anthologyfilmarchives.org/film_screenings/series/45275. 


\section{Bibliography}

“Advertisement for Last House on the Left, The House That Dripped Blood, and The House by the Lake." Real Horrorshow - Poster Gallery, Pinterest. Accessed January 5, 2018. https://i.pinimg.com/736x/b2/37/b5/b237b5e0e68b588b874f80efb7355ce6--vintage-horror-vintageads.jpg.

“American International Pictures, Part 3." Anthology Film Archives. Accessed December 29, 2017. http://anthologyfilmarchives.org/film_screenings/series/45275.

Babler, Olivia. “AGO Film - Individual Screenings (1937-1998),” 2016, in AGO archives.

Bailey, Patricia. "Andre Link \& John Dunning - Feature Film: Maverick producer-distrib team scored at box office." Playback, June 25, 2007. Accessed March 17, 2016.

http://playbackonline.ca/2007/06/25/linkdunning-20070625/.

Bordwell, David, and Kristen Thompson. Film History: An Introduction, $2^{\text {nd }}$ edition. New York: McGrawHill Higher Education, 2002.

Brownstein, Bill. "John Dunning, champion of the Canadian film industry, dead at 84." National Post, September 27, 2011. Accessed February 3, 2017. http://nationalpost.com/entertainment/gregdunning-champion-of-the-canadian-film-industry-dead-at- 84 .

"Cannes Advertisement for Death Weekend," Cinépix. Accessed December 30, 2017. http://www.cinepix.ca/downloads/17/Death\%20Weekend\%20-\%20Screen\%20International\%20\%20Cannes\%201976.pdf

Cherchi Usai, Paolo. "Early Films in the Age of Content; or, 'Cinema of Attractions' Pursued by Digital Means.” In The Blackwell Companion to Early Cinema, edited by André Gaudreault, Nicolas Dulac, and Santiago Hidalgo, 587-610. Hoboken and Oxford: Wiley-Blackwell, 2012.

“Chronology of Motion Picture Film, 1960-1979..Kodak. Accessed January 3, 2018. https://www.kodak.com/us/en/motion/About/Chronology_Of_Film/1960-1979/default.htm.

“Cinepix With \$10-Mil 3-Pic Slate Ups Its Per Pic Budget.” Variety, May 28, 1980.

Clarke, Helen, Mary Hemmings, and Frits Pannekoek. "Controlling the Popular: Canadian Memory Institutions and Popular Culture.” In How Canadians Communicate III: Contexts of Canadian Popular Culture, edited by Bart Beaty, Derek Briton, Gloria Filax, and Rebecca Sullivan, 199-215. Athabasca, AB: Athabasca University Press, Jan 2010.

Corupe, Paul. "Sin and Sovereignty: the curious rise of Cinepix Inc." Take One, March-June 2005: 16-21.

---. 'Canuxploitation! Goin' Down the Road with the Cannibal Girls that Ate Black Christmas. Your Complete Guide to the Canadian B-movie.” Broken Pencil, no. 11, Fall 1999: 12-17. 
---. "From Cinépix to Cineplex: The Studios That Dripped Maple Syrup." Canuxploitation!. Accessed December 30, 2017. http://www.canuxploitation.com/article/studio.html.

---. "(Who's in the) Driver's Seat: The Canadian Brute Unleashed in Death Weekend." The Canadian Horror Film: Terror of the Soul, edited by Gina Freitag and André Loiselle, 91-107. Toronto, Buffalo, and London: University of Toronto Press, 2015.

Cuthbert, Pamela, Peter Morris, and Anna Zuschlag. "Film Distribution in Canada," The Canadian Encyclopedia. Historica Canada. October 6, 2012, edited February 21, 2017. Accessed January 3, 2018. http://thecanadianencyclopedia.ca/en/article/film-distribution-in-canada/.

Daly, Karen D. "Provenance Research in Museum Collections: A Collections Management Perspective." In MRM5: Museum Registration Methods $5^{\text {th }}$ Edition, edited by Rebecca A. Buck and Jean Allman Gilmore, 62-75. Washington: The AAM Press/American Association of Museums, 2010.

"Death Weekend (1976)" The Swedish Film Database. Accessed December 30, 2017. http://www.svenskfilmdatabas.se/en/item/?type=film\&itemid=6376\#release-dates.

"Death Weekend One Sheet." Cinépix, 1976. Accessed December 30, 2017. http://www.cinepix.ca/downloads/17/Death\%20Weekend\%20-

$\%$ 20Cinema\%20Canada\%20one\%20sheet.pdf.

"Death Weekend Press Release." Cinepix.ca, September 30, 1976. Accessed December 12, 2017. http://www.cinepix.ca/downloads/17/Death\%20Weekend\%20\%20Press\%20Release\%20for\%20ope ning\%20-\%20Montreal,\%20September\%2030,\%201976.pdf.

Delaney, Marshall. "You should know how bad this film is. After all, you paid for it." Saturday Night, September 1976, Vol. 90, No. 4: 83-85.

Desbarats, Peter. “The Walt Disney of Sexploitation.” Saturday Night, November 1970, Vol. 85, No. 11: 2830.

Diebel, Linda. "Ilsa's trail of blood and sex has Cinepix riding high.” Montreal Star, July 2, 1977: A2.

Dunning, John with Bill Brownstein. You're Not Dead Until You're Forgotten: A Memoir. Montreal, Kingston, London, and Ithaca: McGill-Queens University Press, 2014.

Flahive, Gerry. "Palace of Guilty Pleasures.” Toronto Star, July 4, 2003.

Gathercole, Sandra. “The Best Film Policy This Country Never Had.” Cinema Canada, June 1978: 28-31.

Hasan, Mark R. "Rituals: Creating the Forest Slasher within the Tax Shelter Era." The Canadian Horror Film: Terror of the Soul, edited by Gina Freitag and André Loiselle, 108-131. Toronto, Buffalo, and London: University of Toronto Press, 2015.

"History of Lions Gate Entertainment Corporation." FundingUniverse. Accessed March 17, 2016. http://www.fundinguniverse.com/company-histories/lions-gate-entertainment-corporation-history/.

"Hollywood North [Program Notes]," ca. July 1978, in AGO archives. 
"House by the Lake, The/Death Weekend." The Internet Movie Database. Accessed January 3, 2017. http://www.imdb.com/title/tt0075922/?ref_=nv_sr_1.

"Independent Film Powerhouse Cinepix Films Announces Name Change to Lions Gate Films Inc. [Press Release].” January 12, 1998, at UofT among Lionsgate Corporate/Legal text files.

“Inventory 35mm Prints Canadian Feature Films,” December 1987, at LAC, Cinépix Inc. file.

Janisse, Kier-La. “Death Weekend [program note].” Fantasia International Film Festival, 2011. Accessed December 29, 2017. http://fantasiafestival.com/2011/en/films/film_detail.php?id=492.

Lee, Betty. "How the taxpayer gets a slice of skin flicks." The Globe and Mail, September 21, 1970: 7.

"Library and Archives Canada Preservation Centre." Library and Archives Canada/Government of Canada. Accessed January 6, 2018. http://www.bac-lac.gc.ca/eng/aboutus/preservation/Pages/preservation.aspx.

Link, André. "Case in Point: The Canadian Film Development Corporation and The Parasite Murders." Is There a Place for Horror Films in Canada's Film Industry?, 1976.

“Lionsgate Entertainment Fonds." University of Toronto Media Commons. Accessed December 29, 2017. https://mediacommons.library.utoronto.ca/fonds/lionsgate-entertainment.

"Lost Dominion Screening Collective Screening Collective, The." The Lost Dominion Screening Collective. Accessed December 29, 2017. http://lostdominion.blogspot.ca/.

Martin, Robert. "Hard sell as important as bikinis at Cannes." The Globe and Mail, March 17, 1978:15.

McDonagh, Maitland. "Tales from the Crypt.” Film Comment, September/October 2002: 66-69:

Melnyk, George. One Hundred Years of Canadian Cinema. Toronto: University of Toronto Press, 2004.

"Ontario Film Institute Listings for Films Released in Toronto 1970-1979," at Toronto International Film Festival Reference Library, Ontario Film Institute Listings Binder.

“Phone message dated 20 February [1978],"at LAC, Cinépix Inc. file.

Playback Staff. “Andre Link \& John Dunning: filmmaking's 'Odd Couple' celebrates 40.” Playback, February 4, 2002. Accessed March 29, 2016. http://playbackonline.ca/2002/02/04/tribute-20020204/.

Pendakur, Manjunath. Canadian Dreams and American Control: The Political Economy of the Canadian Film Industry. Detroit: Wayne State University Press, 1990.

“Receipt from Roger Leger Inc.,” July 12, 1988, at LAC, Cinépix Inc. file.

Rodley, Chris, ed. Cronenberg on Cronenberg. Toronto: Alfred A. Knopf, 1992.

"Scary Movies 7." The Film Society of Lincoln Center. Accessed December 29, 2017. https://www.filmlinc.org/films/death-weekend/. 
Schaefer, Eric. "Bold! Daring! Shocking! True!: a history of exploitation cinema, 1919-1959. Durham NC: Durham University Press, 1999.

Scott, Casey. "Issues in Preservation of Exploitation Cinema." Desperately Seeking MA, October 25, 2011. Accessed December 1, 2017. http://nyumawritings.blogspot.ca/2012/10/issues-in-preservation-ofexploitation.html.

Smoodin, Eric. "As the Archive Turned: Writing Film Histories without Films." The Moving Image 14, 2 (2014): 96-100.

Tadros, Connie. "Commercial Results." Cinema Canada, June-July 1976: 22-23.

Turner, D. J., with French text by Micheline Morisset. Canadian Feature Film Index 1913-1985. Ottawa: Public Archives Canada/National Film, Television and Sound Archives/Minister of Supply and Services Canada, 1987.

---. "Feature Film Production Guide." Cinema Canada, December-January 1976. Toronto: Cinema Canada Magazine Foundation, 9-10.

---. “Inspection Remarks [for Death Weekend],” March 20, 1978, at LAC, Cinépix Inc. file.

Urquart, Peter. 1979: Reading the Tax Shelter Boom in Canadian Film History. Montreal: Department of Art History and Communication Studies, McGill University, 2004.

---. "Film HistoryไFilm Policy: From the Canadian Film Development Corporation to Telefilm Canada." In Self Portraits: the Cinemas of Canada after Telefilm, edited by Tom McSorley and André Loiselle, 29-54. Ottawa: Canadian Film Institute, 2006.

Vatnsdal, Caelum. They Came From Within: A History of Canadian Horror Cinema. Winnipeg: Arbeiter Ring Publishing, 2004.

Williams, Blake. “This Week in Film: Tower, CINSSU's Cult Night Triple Bill, The Free Screen, Reel Artists film festival," blogTO, February 21, 2013. Accessed January 5, 2018.

https://www.blogto.com/film/2013/02/this_week_in_film_tower_cinssus_cult_night_triple_bill_the_ free_screen_reel_artists_film_festival/. 